\title{
A Survey for Hepatitis 'B' Infection among Prison Inmates in Bali Prison, Taraba State, Nigeria.
}

\author{
Monday Iganga Elijah* and Francis james Ireebanije \\ Department of Science Laboratory Technology, Federal polytechnic, Bali, Taraba State, Nigeria.
}

\begin{abstract}
Hepatitis $B$ virus infection (HBV) is common among prisoners suggesting them as one of the main infection source in the community; Hence in this study, we evaluated the sero-prevalence of this infection among jail inmates in Bali prison, Taraba State Nigeria between August and November 2013. The sero-prevalence of Hepatitis $B$ among the random population of sentenced prison inmates was investigated. We examined a total of fifty (50) inmates (49 males and 1 female). All collected blood samples were tested for Hepatitis B surface Antigen antibodies using rapid test strip (Global). An overall prevalence rate of 18\% ( 9 positive inmates) was observed. Male inmates were mostly infected while the only female inmate was not. Inmates between the age group $20-29$ years had higher infection rate. There was significant association $(p<0.01)$ between age, sex and HBsAg sero-positivity in this study. This study confirms the presence of HBsAg among jailed inmates in Bali prison. Regular testing for hepatitis $B$ virus antibodies in prisons is necessary to identify those already infected and those in need of specific health care to help limit further transmission of the disease within and outside the prison. Furthermore, introduction of effective preventive measures is recommended and uninfected inmates should be vaccinated as this will reduce the spread of the disease.
\end{abstract}

Key words: Inmates, HBsAg, Bali prison, Survey, Sero-positivity.

\section{Introduction}

Hepatitis is a general term meaning inflammation of the liver and can be caused by a variety of different viruses such as hepatitis A, B, C, D and E (Mahoney et al, 1999). It is a potential life threatening liver infection and is diagnosed as the inflammation of the liver (Adjei, 2006). Hepatitis B is caused by the hepatitis B virus (HBV), an enveloped virus containing a partially double stranded, circular DNA genome, and classified within the family hepadnavirus (Ganem et al, 2001). Hepatitis may also be caused by toxin such as alcohol, and other viruses that can cause injury to the liver cells including the hepatitis $\mathrm{A}$ and $\mathrm{C}$ viruses. These viruses are not related to each other or to hepatitis B virus and differ in their structure, ways which they are spread among individuals, severity or symptoms they can cause, the way they are treated and outcome of the infection (Nafees, 2008).

Hepatitis B is a global health problem and the most serious type of viral hepatitis. It can cause chronic liver disease and put people at high risks of death thrombosis. It is estimated worldwide that, two billion people (about 1/3 of the world population) have been infected with hepatitis B virus (HBV) and more than 350 million have chronic (long-term) liver infection. High endemicity areas include south-east Asia and the Pacific Basin (excluding Japan, Australia, and New Zealand), sub-Saharan Africa, the Amazon Basin, parts of the Middle East, the central Asian Republics, and some countries in eastern Europe. In these areas, about 70 to $90 \%$ of the population becomes HBV-infected before the age of 40, and 8 to $20 \%$ of people are HBV carriers (Hollinger et al, 2001). Low endemicity areas include North America, Western and Northern Europe, Australia, and parts of South America. The carrier rate here is less than $2 \%$, and less than $20 \%$ of the population is infected with HBV(Mahoney et al, 1999). 30\% to 50\% of children infected between one to four years of age develop chronic infection. About $29 \%$ of adult who were chronically infected during childhood died from Hepatitis B virus related to liver cancer or cirrhosis (Monica, 2005).It has beenreported that hepatitis B related illnesses causes an estimated $1-2$ million deaths per year world wide and 5,000 - 6,000 deathsper yearin America (Blumberg, 2002; HBF, 2005).In Nigeria, Hepatitis B virus (HBV) infection is a major health problem due to its associated mortality. Apart from the asymptomatic nature of the disease in most cases, the documentation of mortality is very poor. Furthermore, many people especially in the poor rural communities do not seek medical assistance early except for major health problems. (Okoye et al, 2006)

Every year there are over 4 million acute clinical cases of $\mathrm{HBV}$, and about $25 \%$ of carriers, 1 million people a year, die from chronic active hepatitis, cirrhosis or primary liver cancer (WHO,2001). The World Health Organization (WHO 1983) estimated that 400 million out of the about 2 billionsubjects infected worldwide are at risk of developinghepatological and non-hepetological manifestations. The most important mode of HBV transmission globally is perinatal, from the mother to her new-born baby, from child to child during early life resulting from blood contact (Gitlin et al 2001). 
According to the recent Iranian national health survey, the prevalence of HBV infection is $1.7 \%$ in the country (Massarrat et al, 2002). 13\% to $47 \%$ of prisoners in USA had HBV infection(Anonymous, 2004). Among infectious diseases globally, Hepatitis B is reported as the $10^{\text {th }}$ leading cause of death, in Nigeria nearly two-third of the population have contact with the virus, while about $20 \%$ of the population are infected with a good number unaware of it. Concerns exist that jails could serve as reservoirs that could amplify transmission of this viral infection in the general community as infected prisoners are released from jails (Muhammad et al, 2011). Compared to the general population, prisoners worldwide continue to demonstrate a significantly higher prevalence of hepatitis B virus infection (Volf, 2008). This phenomenon has been attributed to factors such as high risk sexual behaviour before and during incarceration, intravenous drug use with sharing of syringes and drugs paraphernalia as well as tattooing among inmates (Fayyaz, 2006).

Hepatitis B virus is more common among prison inmates mainly because, most of the inmates come from marginal section of the population where there are intravenous drugs users at which they are highly exposed to the virus and so, they spread the virus to another inmate by sharing sharp objects such as razor, Needles, shaver which are in short supply in the prison and by body contact with body fluid (Solomon, 2004).

The purpose of this study was to estimate the prevalence of hepatitis " $B$ " infection among inmates of Bali prison located in Taraba State, Nigeria. Estimating the prevalence of hepatitis "B" among jail inmates also provides insight for possible ways of transmission and opportunities for preventing infection and the disease.

\section{Materials And Methods}

study population

This study was undertaken at Bali prison in Bali local government Area of Taraba state, Nigeria and study population comprised of 50(1 female and 49 males) randomly selected jail inmates(including new intake and continuously incarcerated).

sample collection

A random sample collection was made between the month of August and November 2013. Venous blood techniques was carried out as described by Monica (2005).

laboratory test for HBsAg

All blood samples were tested for HBsAg antibodies using commercially available one rapid test strip(Global Test Strip) following the manufacture's instructions. All testing was performed by a trained medical laboratory personnel at the laboratory unit, General hospital bali, Taraba State, Nigeria.

Statistical Analysis

Comparison of age and sex were based on the student's t-test. Analysis was conducted using SPSS version 15. $\mathrm{P}<0.001$ was considered as statistically significant.

\section{Results}

A total of 50 inmates ( 1 female and 49 males) were tested. The data presented in this study revealed that, $9(18 \%)$ prisoners were positive while 41 (82\%) inmates were negative.(Table 1). Male inmates population were mostly infected with Hepatitis B virus as compared to the only female prisoner. The most affected age group was between $20-29$ years (Table 1). There was significant association $(\mathrm{p}<0.01)$ between age, sex and HBsAg sero-positivity in this study.

The study shows that, $5(10 \%)$ inmates were illicit drug users and $45(90 \%)$ inmates were not involve in illicit drug use (Table 2). The result also revealed the incarceration of the inmates from $1-12$ months representing $20(40 \%)$ to be the highest, followed by those who stayed $13-24$ months which represents 18 $(36 \%)$ and the least to be 25 months and above representing 12 (24\%) (Table 3).

Table 1: Age and sex distribution of HBV among inmates in Bali prison

\begin{tabular}{lcccccccc}
\hline Male & \multicolumn{5}{c}{ Female } \\
\hline $\begin{array}{l}\text { Age } \\
\text { Years })\end{array}$ & NT & $\begin{array}{r}\text { N+ve } \\
(\%)\end{array}$ & $\begin{array}{c}\text { N-ve } \\
(\%)\end{array}$ & NT & $\begin{array}{r}\text { N+ve } \\
(\%)\end{array}$ & $\begin{array}{r}\text { N-ve } \\
(\%)\end{array}$ & $\begin{array}{r}\text { TN+ve } \\
(\%)\end{array}$ & $\begin{array}{c}\text { TN-ve } \\
(\%)\end{array}$ \\
\hline & & & & & & & & \\
$\leq 19$ & 6 & $2(4)$ & $4(8)$ & 0 & $0(0)$ & $0(0)$ & $2(4)$ & $4(8)$ \\
$20-29$ & 15 & $3(6)$ & $12(24)$ & 0 & $0(0)$ & $0(0)$ & $3(6)$ & $12(24)$ \\
$30-39$ & 14 & $0(0)$ & $13(26)$ & 1 & $0(0)$ & $1(2)$ & $0(0)$ & $14(28)$ \\
$40-49$ & 5 & $2(4)$ & $3(6)$ & 0 & $0(0)$ & $0(0)$ & $2(4)$ & $3(6)$ \\
$\geq 50$ & 10 & $2(4)$ & $8(16)$ & 0 & $0(0)$ & $0(0)$ & $2(4)$ & $8(16)$ \\
\hline TOTAL & $\mathbf{5 0}$ & $\mathbf{9 ( 1 8 )}$ & $\mathbf{4 0}(\mathbf{8 0})$ & $\mathbf{1}$ & $\mathbf{0 ( 0 )}$ & $\mathbf{1 ( 2 )}$ & $\mathbf{9 ( 1 8 )}$ & $\mathbf{4 1 ( 8 2 )}$ \\
\hline
\end{tabular}

Key: NT=No. Tested; N+ve=Positive; $\mathrm{N}$-ve=Negative; $\mathrm{TN}+\mathrm{ve}=$ Total no. Positive; $\mathrm{TN}-\mathrm{ve}=$ Total no. Negative 
A Survey For Hepatitis 'B' Infection Among Prison Inmates In Bali Prison, Taraba State, Nigeria.

Table 2: Drug history Among inmates in Bali prison

\begin{tabular}{lcc}
\hline Illicit drug use & Number of inmates & Percentage (\%) \\
Yes & 5 & 10 \\
No & 45 & 90 \\
Total & $\mathbf{5 0}$ & $\mathbf{1 0 0}$ \\
\hline
\end{tabular}

Table 3: Length of incarceration in Bali prison

\begin{tabular}{lcc}
\hline Incarceration (Months) & Number of inmates & Percentage (\%) \\
$1-12$ & 20 & 40 \\
$13-24$ & 18 & 36 \\
$25 \&$ Above & 12 & 24 \\
Total & $\mathbf{5 0}$ & $\mathbf{1 0 0}$ \\
\hline
\end{tabular}

\section{Discission}

The survey conducted revealed that, nine (9) prison inmates (representing $18 \%$ ) were positive while fourthy one (41) inmates (representing $82 \%$ ) were negative (Table 1). The result shows that, Bali prison inmates were infected with hepatitis B virus. The infection seen in Bali prison, may be attributed to the large population of prisoners (0ver 50), which result to overcrowding. We observed that Hepatitis B virus infection is high in male inmates (Table 1) and this was consistent with the findings of Mohammed, et al., (2011) in which male inmates population were highly positive for all these infection (HBV, HBC and HIV) as compared to women prisoners and this could be as a result of the restrictive nature of the prison environment, the nonavailability of clean/sterilized shaving instruments, probably sexual activity among male within the prison, reuse of contaminated razor blades, alcoholism and possibly sharing of cups, spoons and toothbrush. (Monica, 2005)

The $18 \%$ sero-positivity reported in this study is far higher than the $5.2 \%$ reported by Babalola et al,(2013) among selected tertiary institution students in Ogun state, Nigeria; and the 12.0\% reported among pregnant women attending ant-natal clinic at central hospital, warri, Delta State (Ophori etal,2004).

The age of inmates may have also contributed especially young men between the ages of $20-29$ years with factors such as high sexual behaviour before and during incarceration, intravenous drug use with sharing of syringes and tattooing among inmates. Also the poor condition prevailing in the prison could contribute to the higher prevalence of Hepatitis B virus among the prisoners. The presence of hepatitis B virus among inmates is a cause for continuing public health concern because the incarcerated represent an extremely important segment of the community, especial with regard to communicable disease. We also observed that inadequate medical facilities, staff and access to good health care delivery within and outside the prison could also contribute to the prevalence of hepatitis B virus among Bali prison inmates. This corroborates the findings of Muhammad et al., (2011) where he observed that inadequate medical facilities and staff in the Lahore Jail and access to appropriate health care outside the prison system was very difficult for the inmates.

\section{Conclusion}

Our study revealed the presence of Hepatitis B Virus among prison inmates in Bali prison where $18 \%$ were infected with the disease. In view of the observed presence of the virus among prison inmates, regular testing for hepatitis B virus antibodies in prisons is necessary to identify those already infected and those in need of specific health care to help limit further transmission of the disease within and outside the prison. Furthermore, introduction of effective preventive measures is recommended and uninfected inmates should be vaccinated as this will reduce the spread of the disease.

\section{CONFLICT OF INTERESTS}

There are no conflict of interest about all of the authors.

Aknowledgment

The authors are grateful to the authority of Nigeria Prison Service Bali, and to the Department of Medical Laboratory Science, General Hospital Bali, Taraba State, for providing the necessary facilities used in this study. 


\section{References}

[1]. A. AAdjei, H. B. Armah, F.Gbagbo, W.K. Ampofo, I. Quaya, I. Hesse and G.Mensah, Prevalence of Human Immunodeficiency Virus, Hepatitis B Virus Hepatitis C Virus and Syphilis prison inmates and officer at Nsawam and Accra, Ghana,Journal of medical Microbiology,55(5), 2006, 593 - 597.

[2]. E.A. Alikor and O.N. Erhabor, Sero-prevalence of hepatitis B surface antigenamia in children in a tertiary health institution in the Niger Delta of Nigeria. Nigerian Journalof medicine, 16(3), 2007,250-1.

[3]. J. Amin, H. Yousuf, A. Mumtaz, M. Iqbal, R. Abmed, S Z. Adhami, and K Malik, Prevalence of Hepatitis B surface Antigen and anti-hepatitis C virus. professional medical Journal,11, 2004334.

[4]. Anonymous, Centres for Disease Control and Prevention. Transmission of hepatitis B virus in correctional facilities.2004, Georgia, 1999-2002. MMWR, 53(30),678-81.

[5]. S. Aziz, A A. Memon, H I. Tily, K. Rashed, K. Jehangir, Prevalence of HIV, Hepatitis B and C among Health workers of civil Hospital, Karachi,Journal of Pakistan medical association, 52 (3) 2002, 92.

[6]. E T. Babalola, O B. Ainabe and I O. Okonkwo, Confirmation of hepatitis B surface antigen(HBsAg) among selected Tertiary institution students in Ogun State, Nigeria, Nat. Sci, 11(3), 2013,107-113.(ISSN:1545-0740). http://www.sciencepub.net/nature.16

[7]. L B, Babudieri, L. Sarmati, G. Starnini, L. Dori, and B. Suligori, Correlates of HIV, HBV and HCV infection in a prison inmates population: results from a multicentre study in Italy. Journal of Medical Virology,76 (3),2005,311 - 317.

[8]. B.S.Blumberg, Hepatitis B: The Hunt for a Killer Virus(London, Princeton University Press, pp264, 2002).

[9]. C. A. Esquivel, E. Sablon, S.M. Garcia and S.E. Martinez, Hepatitis Virus and HIV infections in inmates of a state correctional facility in Mexico, Journal of epidemiology and infection, 133 (4), 2005,679 - 685.

[10]. M. Fayyaz, M.A. Qazi, M. Ishaa, G.M chaudhary, M.H. Bukhari, Frequency of hepatitis B and C sero positivity in prisoners,Journal of Biomedical, 22(2), $2006 \mathbf{5 5 - \mathbf { 5 8 } .}$

[11]. D. Ganem, R.J. Schneider, Hepadnaviridae: The Viruses and their replication (In: D.M. Knipeet al., eds. Fields Virology, 4th ed. Philadelphia, Lippincott Williams \& Wilkins, 2923-2969 2001).

[12]. N. Gitlin, Hepatitis B: diagnosis, prevention, and treatment. Clinical Chemistry, 1997, 43:1500-1506.

[13]. HBF92005). Hepatitis B Foundation: Cause for a cure, Available at $>$ http://www.hebp.org $\backslash$ pdf $<$ Accessed March 13, 2006

[14]. F.B. Hollinger, T.J. Liang,Hepatitis B Virus(In: D.M. Knipe et al., eds. Fields Virology, 4th ed. Philadelphia, Lippincott Williams \& Wilkins, 2971-3036, 2001)

[15]. F.J. Mahoney, M. Kane,Hepatitis B vaccine,(In: Plotkin SA and Orenstein WA, eds. Vaccines, 3rd ed. Philadelphia, W.B. Saunders Company, 158-182 1999).

[16]. M.S. Massarrat, S. Tahaghoghi-Mehrizi, Iranian National Health Survey: A Brief report. Arch Irn Med, 5, 2008,73-9.

[17]. C. Monica,District laboratory practice in Tropical countries, second edition, Part 2, (United kingdom, Cambridge University press, $250-253,2005)$.

[18]. N. Muhammed, J. Ghazala and A. Ishtiaq, Jail population; a survey for Hepatitis B virus, Hepatitis C virus and Human imunodificiency virus $\quad$ infections. Professional medical Journal, 18 (4), 2011, 697 - 702.

[19]. M. Nafees,A. Ishris,Z.U. Latif and U.L. Irshad, Pre-operative screening for HBV and HCV infections: A preventive measure! Where are we today, journal of Biomedical,24(2), 2008,108-112.

[20]. I.C. Okoye and S.A. Samba, Sero-epidemic survey of hepatitis B in a population of Northern Nigeria. Animal Research International, 3(2), 2006, 485-488.

[21]. E.A. Ophori, A. Wagbasoma, O. Atunumu, Sero-prevalence of hepatitis B among pregnant women attending anti-natal clinic at central hospital ward. Nigerian Journalof Microbiology, 18, 2004, 1-2.

[22]. E. Pontali and F. Ferrari, Prevalence of Hepatitis B virus and / or Hepatitis C virus Co-infections in prisoners infected with the Human immunodeficiency virus. International journal of prison Health,4 (2), 2008,77 - 82.

[23]. L. Solomon, C. Flynn, K. Muck and J. Vertefeuille,Prevalence of HIV, syphilis, hepatitis B, and hepatitis C among entrants to Maryland correctional facilitiesJournal of urban Health, 81 (1), 2004,25 - 37.

[24]. V. Volf, D. Marx,L. Pliskova, L. Surnegh and A. celko, A survey of hepatitis B and C prevalence amongst the homeless community of praque. European journal of public Health, 18(1), 200844 - 47.

[25]. World Health Organization. Introduction of hepatitis B vaccine into childhood immunization services, Geneva, WHO, 2001 (unpublished document WHO/V\&B/01.31 available on request from Department of Vaccines and Biologicals, World Health Organization, 1211 Geneva 27, Switzerland). 